\title{
First Quantitative Data on Red Sea Deep Benthos*
}

\author{
H. Thiel
}

Institut für Hydrobiologie und Fischereiwissenschaft der Universität Hamburg, Zeiseweg 9, D-2000 Hamburg 50, Federal Republic of Germany

\begin{abstract}
The quantitative distribution of the benthos in the deep Red Sea has never been studied before. First data on the meiofauna from depths between 500 and $2000 \mathrm{~m}$ are presented, and the low faunal densities are discussed in respect to the low productivity of the Red Sea, its peculiar temperature regime with $21.5^{\circ} \mathrm{C}$ down to more than $2000 \mathrm{~m}$ depth and the presumably high degradation rates of organic matter. Meiofaunal numbers of bathyal depths in the Red Sea correspond to data obtained from central oceanic, abyssal regions of the Atlantic and Pacific Oceans.
\end{abstract}

\section{INTRODUCTION}

During the last 30 years information has been gathered on the faunal density of the deep-sea benthos in all oceans (Thiel, 1975). However, the only expeditions which sampled deep benthos of the Red Sea remained those of the Austrian 'Pola' during the two winters of $1895 / 96$ and $1896 / 97$. Dredges were used for bottom sampling and interest focussed on taxonomical problems; quantitative data were not obtained during this early period of benthos research.

In close connection with the exploratory and prepilot phases for mining the metalliferous muds from the deep basins of the Red Sea central graben, I had the opportunity to participate in research cruises of the German R. V. 'Sonne' in 1977 and R. V. 'Valdivia' in 1979 (Thiel and Rumohr, 1979; Thiel, in press a; Karbe et al., in press).

The deep Red Sea exhibits unique features which promise fascinating results on its biological system. In general, deep-sea environments are marked by largely constant physical conditions, including low temperatures of $4^{\circ}$ to $1^{\circ} \mathrm{C}$ or even less, on a world-wide scale. However, the Red Sea is characterized by a special feature: down to the greatest depth of more than 2000 m, a temperature of $21.5^{\circ} \mathrm{C}$ prevails. A narrow basin with a maximal width of $300 \mathrm{~km}$, the Red Sea features a length of $2000 \mathrm{~km}$. It covers tropical and subtropical latitudes and receives little rain (less than $100 \mathrm{~mm}$ year $^{-1}$ in the north; less than $250 \mathrm{~mm}$ year $^{-1}$ in the south) and land run off. At its southern boundary, the

\footnotetext{
- Investigations on the Red Sea Deep Benthos - No. 2.
}

Red Sea is locked off from the Indian Ocean by a sill of about $100 \mathrm{~m}$ depth, prohibiting the penetration of cold deep water. During winter, the water at the basin's northern end cools off to about $21.5^{\circ} \mathrm{C}$; attaining maximum density it sinks to constitute the water layers beyond about $200 \mathrm{~m}$ depth. Thus the winter temperature of the northern Red Sea determines the temperature of the deep water masses.

\section{MATERIAL AND METHODS}

During the 'Sonne' cruise 02, samples were taken along a depth transect at about $21^{\circ} \mathrm{N}$ (central Red Sea) in the western part from the base of the steep reefadjacent slope, on the deep terrace, and from the slope to the bottom of the central graben (Tab. 1). Further sampling was performed during 'Valdivia' cruise 22 with stations covering the eastern side of the Red Sea. This paper concentrates on meiofauna abundance in the western Red Sea and presents some information on macro- and megafauna.

Meiofauna was sampled with a box grab cutting an area of $50 \times 50 \mathrm{~cm}$. During lowering, the grab top was opened by $52 \%$ to prevent bow-wave effects; it was closed by lids when retrieved (Thiel, in press a). From each sample, 5 subsamples were collected using a medical syringe of $3.8 \mathrm{~cm}^{2}$ area from along a middleline of the box spaced at about $10-\mathrm{cm}$ intervals. Sorting was performed under a stereomicroscope after rose bengal-phenol staining. The lower size limit of the organisms considered was limited by a $40-\mu \mathrm{m}$ mesh size sieve. All data were expressed as numbers $10 \mathrm{~cm}^{-2}$ 
sediment-surface area. Additional sampling for larger faunal components was done with grabs, a closing beamtrawl, and a phototrap; the megafauna was recorded with a photosled (Thiel, in press a).

\section{RESULTS AND DISCUSSION}

The data from 5 grab samples and from each of the 5 meiofauna subsamples are presented in Table 1.

The composition of meiofaunal taxa turned out to be similar to that found in other deep-sea environments. Nematoda rank first, at $81 \%$; they are followed by Copepoda Harpacticoidea $(7.5 \%)$, Polychaeta $(5.5 \%)$ and nauplii $(3.8 \%)$. The other taxa comprise less than $1 \%$ each: Tardigrada, Kinorhyncha, Ostracoda, Acari, Bivalvia, Scaphopoda, and Gastropoda. In many other deep-sea regions the nematodes account for 90 to $95 \%$ while the other taxa are less important.

Parallel to the low standing stock in most subsamples, sediment penetration is restricted to the upper 1 or $2 \mathrm{~cm}$ of the sediment surface layer. In the more densely populated areas, meiofauna was found down to $4 \mathrm{~cm}$ sediment depth; its percentage distribution was $66,25,6$ and $3 \%$, respectively, for each $1-\mathrm{cm}$ layer.

Comparing meiofaunal numbers along the transect, there is a general trend of decrease with increasing water depth and distance from the shore; this was expected from earlier results on meio- and macrofauna obtained in other ocean areas (e.g. Filatova, 1969; Sanders and Hessler, 1969; Thiel, 1975). The explanation for this decrease, however, is the dependence of faunal densities on the amount of food available to the benthos (Thiel, 1975, 1979). This probably accounts for the variation in abundance of meiofauna along the Red Sea transect. The shallowest station was situated adjacent to the reef Shab Baraja, on the base of a steep slope, dropping off to a depth of more than $400 \mathrm{~m}$ within about $2 \mathrm{~km}$. From the reef area organic matter is transported downslope.

The subsequent two stations are located on the wide tenace which slopes gently and irregularly to about $850 \mathrm{~m}$ depth in this transect. Down-slope food transport from the reef area decreases with increasing distance, and thus may not reach the areas sampled. However, some material is actually transported from very shallow waters to the open sea. Mudfloats composed of bluegreen algae, diatoms, meiofauna and insect bodies were observed drifting along the sea surface together with jellyfish and siphonophores. These floats derived from inshore waters where bluegreen algae and diatoms covered the fine-grained sediment with a dense blanket. Oxygen developed from the algae was caught within the mat and, scavenging some sediment and meiofauna, was lifted upward like a balloon, possibly with the aid of some wave action or other mechanical forces, and drifted into the open sea. Many of these mudfloats were observed during April 1979; their size ranged up to $40 \mathrm{~cm}^{2}$. It is not known how far these floats drift. They were observed at least $100 \mathrm{~km}$ from the nearest coast and the prevailing winds suggest a much longer travelling distance. Ultimately, these natural floats will sink, at least under the influence of heavy waves; this occurred frequently with wind force 6 to 8 Beaufort; thus most of the organic material becomes a food source for deepliving communities.

The lowest meiofaunal density was discovered in the sample from $1549 \mathrm{~m}$ depth, taken from the steep slope of the central graben. If the assumption is correct that organic matter will not settle in such a sloping environment, but is transported further down-slope, the higher faunal density at $1977 \mathrm{~m}$ in the central graben may be explained. Additionally, organic matter dumped from ships should be taken into consideration. Most of the heavy ship traffic follows the central Red Sea and their organic wastes may well exceed that part of the natural production which settles from the water column to the bottom.

Investigations on the quantification of biological processes have rarely been undertaken in the Red Sea; hence details of energy flux in the water column can only be a matter of speculation. Two arguments speak for a low downward transport of organic materials to the seabed.

Firstly, the open Red Sea is a typical oceanic bluewater area exhibiting a low standing stock in phyto-

Table 1. Station data and number of meiofauna $\mathrm{Crn}^{-2}$ from 5 grab samples

\begin{tabular}{|c|c|c|c|c|c|c|c|c|}
\hline \multirow{2}{*}{$\begin{array}{l}\text { Station } \\
\text { number }\end{array}$} & \multirow{2}{*}{$\begin{array}{l}\text { Date } \\
1977\end{array}$} & \multirow{2}{*}{$\begin{array}{c}\text { Serial } \\
\text { number }\end{array}$} & \multirow{2}{*}{$\begin{array}{l}\text { Depth } \\
\text { (m) }\end{array}$} & \multicolumn{2}{|c|}{ Position } & \multicolumn{2}{|c|}{ Meiofauna $10 \mathrm{~cm}^{-2}$} & \multirow[t]{2}{*}{ Tota } \\
\hline & & & & $\mathrm{N}$ & $E$ & Metazoa & Foraminifera & \\
\hline $\mathrm{SO}-33$ & 16 Oct. & $\mathrm{KG} 775$ & 507 & $20^{\circ} 53.70^{\prime}$ & $37^{\circ} 24.45^{\prime}$ & 407 & 206 & 613 \\
\hline $\mathrm{SO}-28$ & 16 Oct. & KG 774 & 733 & $21^{\circ} 13.10^{\prime}$ & $37^{\circ} 25.60^{\prime}$ & 160 & 47 & 207 \\
\hline $\mathrm{SO}-40$ & 18 Oct. & $\mathrm{KG} 778$ & 831 & $21^{\circ} 13.50^{\prime}$ & $37^{\circ} 39.60^{\prime}$ & 53 & 66 & 119 \\
\hline $\mathrm{SO}-48$ & 20 Oct. & $\mathrm{KG} 780$ & 1549 & $21^{\circ} 13.40^{\prime}$ & $37^{\circ} 59.02^{\prime}$ & 39 & 8 & 47 \\
\hline $\mathrm{SO}-22$ & 15 Oct. & KG 772 & 1977 & $21^{\circ} 14.20^{\prime}$ & $38^{\circ} 07.30^{\prime}$ & 127 & 9 & 136 \\
\hline
\end{tabular}


and zooplankton (Halim, 1969; Kimor, 1973). Plankton standing stock was observed to decrease from south to north and the same holds for the total pigment concentration during the SW-monsoon, while the opposite pigment distribution was measured during the NEmonsoon. Data on chlorophyll concentration cannot give productivity estimates, but the generally low values suggest low productivity. This assumption is supported by measurements of chloroplastic pigments and ${ }^{14} \mathrm{C}$-production values obtained during the 'Valdivia' cruise in 1979 (Moiges and Weikert, personal communication).

The second argument concerns the rates of recycling which, under high temperature conditions, can be assumed to be rather fast. Mean surface temperatures range from $25^{\circ}$ to $32{ }^{\circ} \mathrm{C}$ in the south to $21.3^{\circ}$ to $27.9^{\circ} \mathrm{C}$ in the north, and temperature decreases to $21.5^{\circ} \mathrm{C}$ between surface and about $200 \mathrm{~m}$ depth (Morcos, 1970).

The speed of degradation processes in response to temperature cannot be deduced on a $Q_{10}$-basis from observations in other geographic regions, because of differing species composition of the communities, and because of species or enzyme adaptation to such hightemperature environments. But degradation of organic matter can be assumed to be faster and, by inference, this would reduce the amount transported to the bottom and its availability as a liable food source. Degradation of organic substance was found by Weikert (personal communication) to be high in the oxygen minimum layer around $400 \mathrm{~m}$ depth. This was indicated by relatively low values for organic substances and high values of ash within the seston. Additionally, peak concentrations of phosphate and silicate were measured in the oxygen minimum zone, showing the breakdown of organic matter above this depth, with only small amounts sinking to the seabed.

Echosounder records have shown that an intensive vertical migration exists in the Red Sea. Several species of sergestid, pandalid and penaeid shrimp, of myctophids and other fishes were caught in different layers during day and night, and were recorded on an echograph. Feeding in the upper 100 or $200 \mathrm{~m}$ during night, they transport organic matter down to 500 or even $750 \mathrm{~m}$ depth and defecate during the day in these depths. Most of the organisms involved are rather small, compared to other oceanic regions and, again, food transport for the deep benthos seems to be rather limited. This food source crumbles into small particles, which spreads over the sea bed.

Food availability has been suggested to represent the essential limiting factor which controls meiofaunal density (Thiel, 1975, 1979). A comparison with meiofaunal densities recorded at similar depths in other ocean regions reveals striking differences. At the sampling site close to the steep, reef-adjacent slope Red Sea samples contain only one quarter the number of organims per areal unit as compared to different Atlantic samples; however, in the Mediterranean Sea about the same number or even less was counted by Vivier (1975). Values for the deep terrace and for the steep central graben slope may be only one twentieth those of other regions. For the meiofauna stock of the central graben with its food-trapping function and, possibly, some artificial food supply from ships, the reduction in numbers ranges between one third and one sixth.

Another approach for data comparison is the search for areas with similar faunal densities irrespective of their depth of occurrence. Meiofauna standing stock in the range from 40 to 160 individuals $10 \mathrm{~cm}^{-2}$, or even more, were sorted from Atlantic and Pacific abyssal plains between 5000 and $6000 \mathrm{~m}$ deep (Burnett, 1979; Thiel, 1979, in press b). Thus the deep terrace and the central graben of the Red Sea seem not to receive more labile organic matter than central oceanic, typically oligotrophic regions.

Since the results presented here are based only on few meiofaunal samples they may be rather tentative. However, further evidence in favour of the conclusions drawn is provided by several additional observations. The samples collected in 1979 seem to fall into the same range of meiofaunal densities. Successful trawls caught small numbers of animals. Photosled surveys revealed only a few megabenthic organisms and very restricted bioturbation, dominated by one specific assemblage of holes and mounds.

All observations presented are consistent with each other and are in agreement with results from other oceans. The deep Red Sea can thus be defined as a biologically low-energy habitat.

Acknowledgements. I am grateful to cruise leader Dr. K. Bäcker, Preussag-AG, Hannover, and to the crew of R. V. 'Sonne' for extended technical assistance; to $\mathrm{R}$. Theeg and $\mathrm{M}$. Türkay for help during sampling at sea; to B. Fitschen and $\mathrm{K}$. Schrey for sample sorting; and to Dr. John S. Gray, Osio, for the improvement of my English text. The Saudi Sudanese Commission for the Exploitation of the Red Sea Resources funded these investigations.

\section{LITERATURE CITED}

Bumett, B. R. (1979). Microbiota and meiofauna. Sandia Lab. Ann. Rep., 1978, 1-19.

Filatova, Z. A. (1969). Quantitative distribution of deep-sea benthic fauna. In L. A. Zenkevich (Ed.), Deep-Sea Bottom 
Fauna, Pleuston. Biol. Tikh. Okean. Tikii Okeana, Isdated Nauka, Moskva, 7. pp. 234-252 (Transl. U. S. Naval Hydrogr. Off., 1970).

Halim, Y. (1969). Plankton of the Red Sea. Oceanogr. mar. Biol., 7, 231-275.

Karbe, L., Thiel, H. and Weikert, H. (in press). The risk of mining metalliferous sediments from the deep Red Sea. Helgoländer wiss. Meeresunters.

Kimor, B. (1973). Plankton relations of the Red Sea, Persian Gulf and Arabian Sea. In B. Zeitschel and S. A. Gerlach (Eds), The Biology of the Indian Ocean. Ecological Studies 3. Springer, Heidelberg. pp. 221-232.

Morcos, S. A. (1970). Physical and chemical oceanography of the Red Sea. Oceanogr. mar. Biol., 8, 73-202.

Sanders, H. L. and Hessler, R. R. (1969). Ecology of the deepsea benthos. Science, N. Y., 163, 1419-1424.
Thiel, H. (1975). The size structure of the deep-sea benthos. Int. Revue ges. Hydrobiol., 60, 575-606.

Thiel, H. (1979). Structural aspects of the deep-sea benthos. Ambio, Spec. Rep., 6, 25-31.

Thiel, $H$. (in press a). Benthic investigations of the deep Red Sea. Cruise Reports: R. V. 'Sonne' - MESEDA I (1977) and R. V. 'Valdivia' - MESEDA II (1979). Courier Forsch. Inst. Senckenberg.

Thiel, H. (in press b). Meiobenthos and Nanobenthos. In G. T. Rowe (Ed.), The Sea, 8. Wiley, Chichester.

Thiel, H. and Rumohr, H. (1979). Photostudio am Meeresboden. Umschau, 79, 469-472.

Vivier, M.-H. (1975). Le meiobenthos du Canyon de Cassidaigne. Influence de deversement de boue rouge d'alumine sur la nematofaune. Thèse l'Université d'AixMarseille.

This paper was submitted to the editor; it was accepted for printing on November 8,1979 . 